\title{
TWIERDZA KŁODZKO POMNIKIEM HISTORII? \\ ROLA OCHRONY ZABYTKÓW W KONTEKŚCIE I WOBEC POLITYKI
}

\section{STOKLASEK-MICHALAK Joanna ${ }^{1}$}

1 Joanna Stoklasek-Michalak, kustosz Muzeum Ziemi Kłodzkiej w Kłodzku, Dyrektor Twierdzy Kłodzko https://orcid.org/0000-0003-2292-7192

ABSTRAKT: Twierdza Kłodzko - niekwestionowany świadek burzliwych wojen śląskich między dwoma mocarstwami: cesarską Austrią i rosnącymi w siłę Prusami, których przebieg zmienił mapę XVIII-wiecznej Europy, ale przede wszystkim obiekt stanowiący wyjątkowy w skali Europy przykład nowożytnej architectura militaris, gdzie krzyżują się rozwiązania architektoniczne kilku szkół fortyfikacyjnych, zachowane do dziś i czyniące z kłodzkiej twierdzy swoistą encyklopedię fortyfikacji pozostaje poza listą zabytków uznanych za pomniki historii.

Podjęte w 2009 r. starania o wpisanie twierdzy na tę listę prestiżowych zabytków nie przyniosły spodziewanego rezultatu, a miniona dekada dostarcza wielu cennych wniosków na temat roli i zakresu ochrony zabytków zarówno wobec lokalnej, jak i centralnej polityki.

Niniejszy artykuł stanowi próbę syntetycznej prezentacji przypadku Twierdzy Kłodzko w związku zponowniepodjętą próbą uzyskania tytułu pomnika historii. Jest równieżechemgłosów koncentrujących się na dziedzictwie stricte polskim, wybrzmiałych podczas konferencji Pomniki Historii - ochrona, zarządzanie, promocja.

SŁOWA KLUCZE: Twierdza Kłodzko, fortyfikacje, architectura militaris, wojny śląskie

\section{Twierdza Kłodzko - rdzeń Kotliny Kłodzkiej}

Twierdza Kłodzko to monumentalny kompleks nowożytnych fortyfikacji o łącznej powierzchni wynoszącej ok. 52 ha (fot.1). Obejmuje on Twierdzę Główną (ulokowaną na Górze Zamkowej w bezpośrednim sąsiedztwie rynku miejskiego, w miejscu istniejącego uprzednio zamku, a wcześniej drewnianego grodu, fot. 2), fort pomocniczy Owcza Góra² (na przeciwległym brzegu Nysy Kłodzkiej, fot. 3), a także położone pomiędzy tymi fortami dawne Przedmieście

2 Wpis do rejestru zabytków pod nr 143/A/02/1-17 z 02.12.2002 r. 
Ząbkowickie ${ }^{3} \mathrm{z}$ wydajnym zapleczem technicznym i aprowizacyjnym (fot. 4). Twierdza Kłodzko, wraz z fryderycjańskimi fortecami w Głogowie, Świdnicy, Wrocławiu, Srebrnej Górze, Nysie i Koźlu, stanowi ogniwo jednej z nielicznych w Europie i jedynej na obszarze Polski, wielkiej XVIII-wiecznej europejskiej linii obronnej. Linia ta wyznacza jednocześnie granicę i punkty zapalne krwawego konfliktu pomiędzy tracącą hegemonię Austrią Habsburgów, a rosnącymi w siłę Prusami Hohenzollernów. Jak pokazała historia, rozstrzygnięcia wojen śląskich diametralnie zmieniły ówczesną mapę Europy oraz wprowadziły nowy, trwały układ sił.

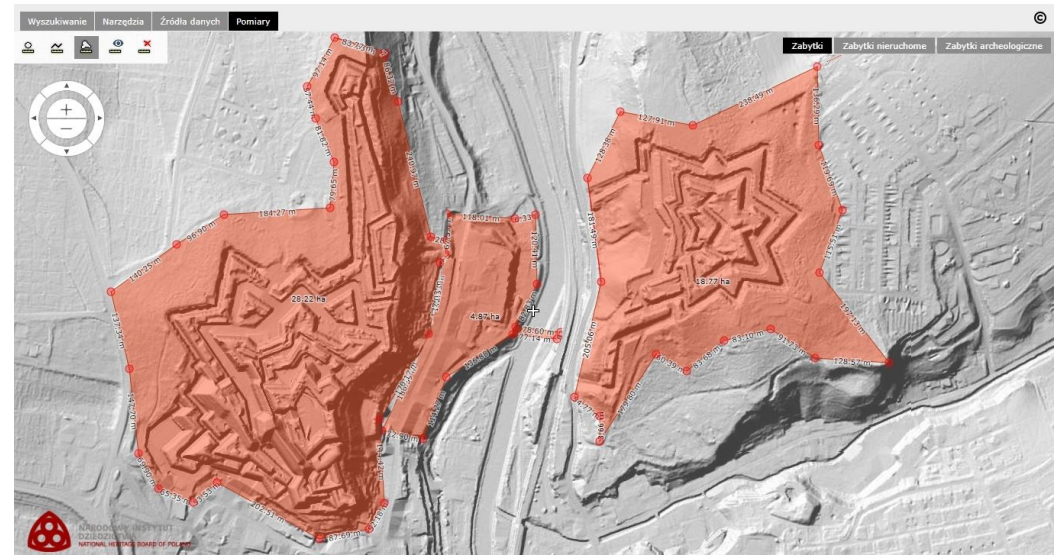

Fot. 1 Obszar Fortecznego Parku Kulturowego - Twierdza Kłodzko. Od lewej: Twierdza Główna, dawne Przedmieście Ząbkowickie i Fort Owcza Góra (źródło: Narodowy Instytut Dziedzictwa, dostęp: 21.09.2017)

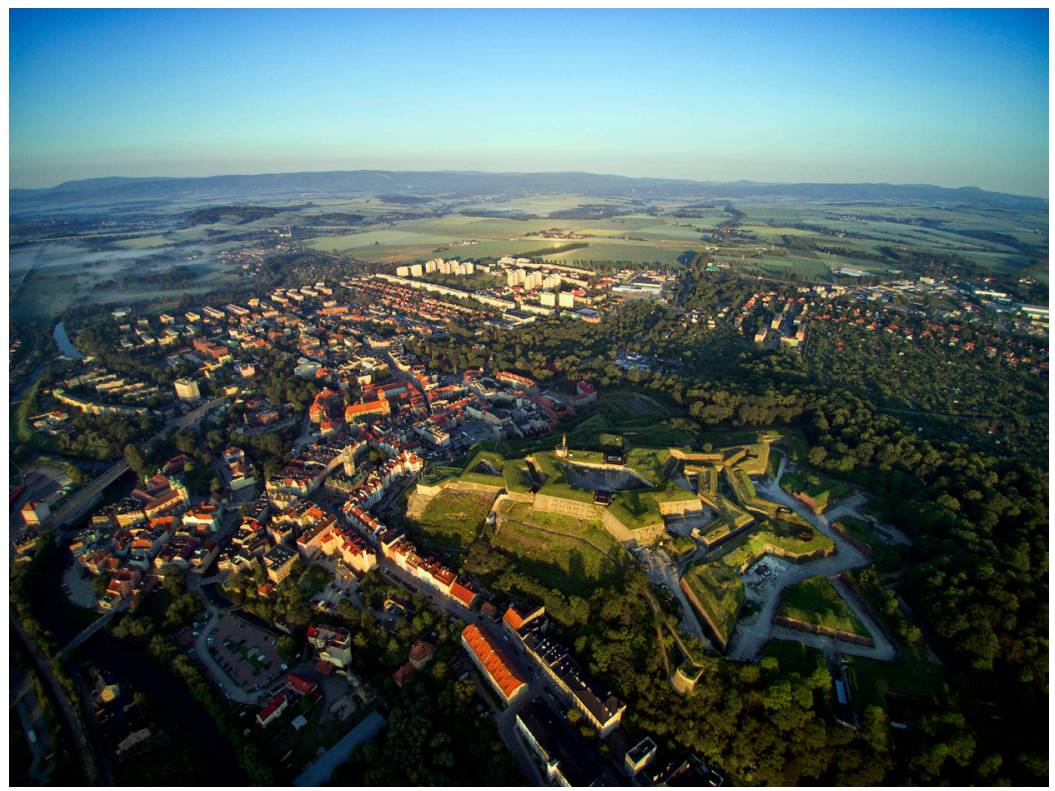

Fot. 2 Twierdza Główna z lotu ptaka w orientacji zachód - wschód (fot. G. Basiński)

3 Obecna ulica Łukasińskiego. Wpis do rejestru zabytków jako cześć ośrodka historycznego miasta pod nr 370 z 25.11.1956 r. 


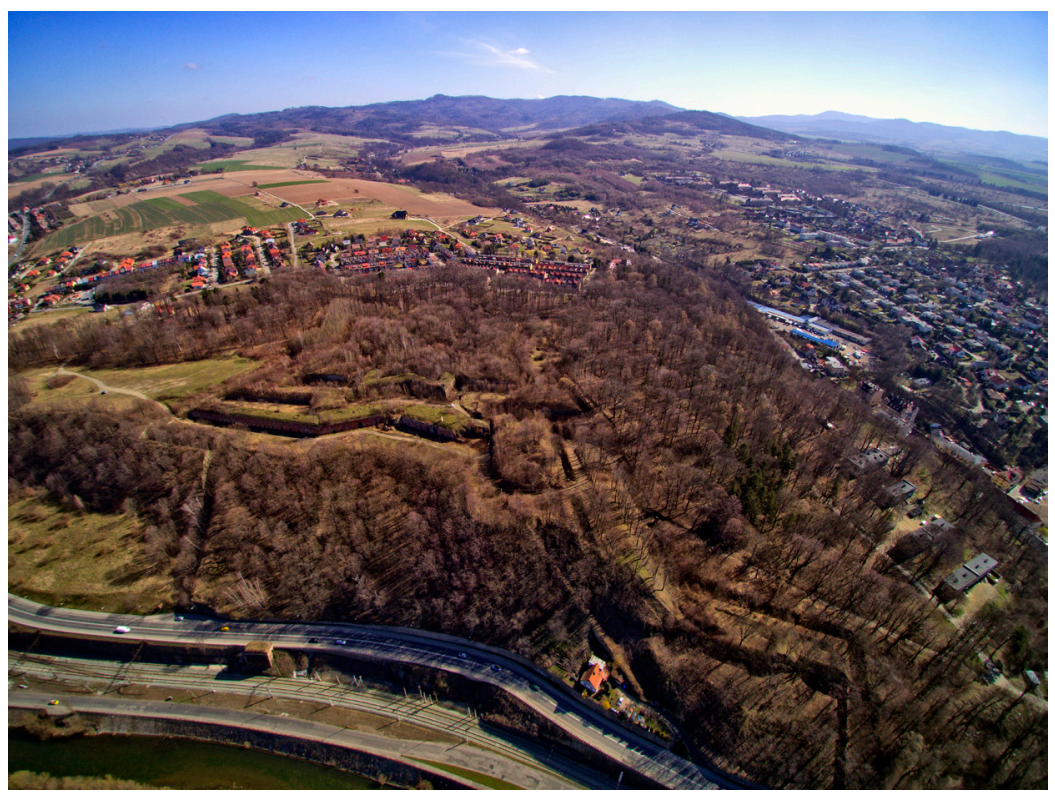

Fot. 3 Widok z lotu Ptaka od zachodu na Fort Owcza Góra (fot. G. Basiński)

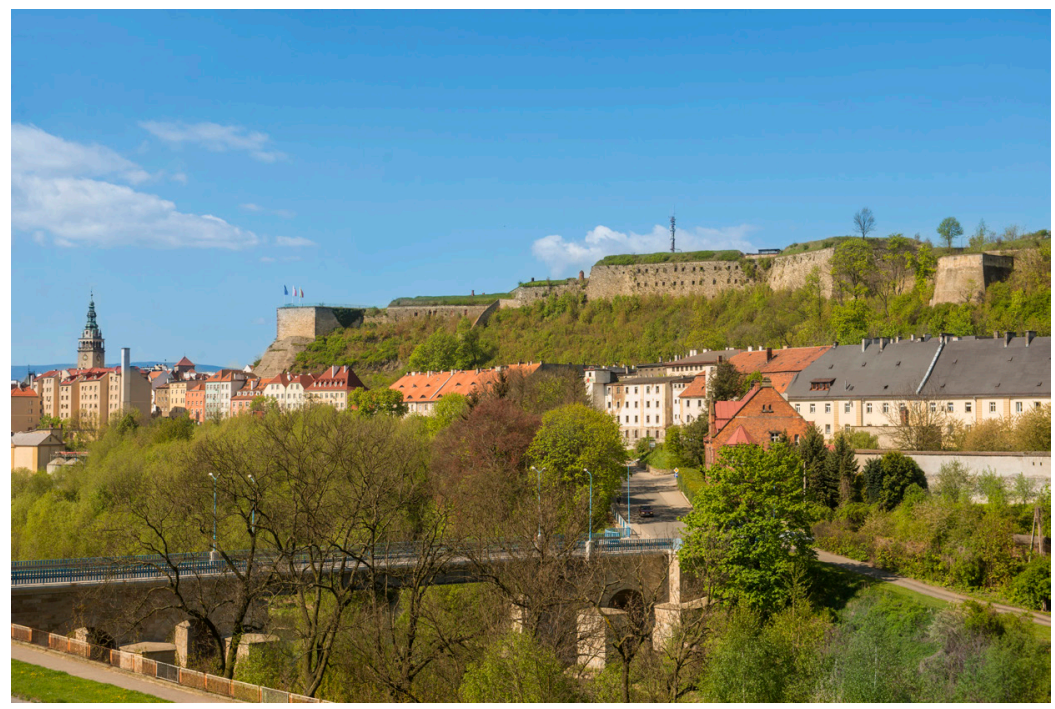

Fot. 4 Widok na Twierdzę Główną i dawne Przedmieście Ząbkowickie z koszarami i spichlerzami. Na pierwszym planie dawny most śluzowy nad Nysą Kłodzką (fot. M. Solska) 
Jako obiekt o autonomicznych walorach, Twierdza Kłodzko wyróżnia się integralnością zespołu i wyjątkowymi atrybutami, co czyni z niej unikatowy zabytek nowożytnej europejskiej architectura militaris, na której swoje piętno na przestrzeni dwóch wieków odcisnęli tacy uznani fortyfikatorzy, jak: Walenty von Säbisch (fortyfikator m. in. Wrocławia i Świdnicy), Jacopo Carove (pochodzący z Włoch architekt doby baroku), inżynier i generał w armii pruskiej Gerhard Cornelius von Walrave, inżynier wojskowy Friedrich Christian von Wrede, inżynier wojskowy w pruskiej służbie Franz Ignatz Pinto z Piemontu oraz pruski pułkownik Ludwig Wilhelm Regler.

Twierdza powstawała ${ }^{4}$ stopniowo na wcześniejszych zabudowaniach, obejmujących ośrodek władzy cywilnej (od $981 \mathrm{r}$. gród, od XII w. kilkakrotnie przebudowywany zamek) oraz kultu religijnego (od poł. XIV w. kompleks klasztorny augustianów). Napięta sytuacja między Piastami Śląskimi a książętami czeskimi, dotycząca m. in. panowania na Śląsku i Ziemi Kłodzkiej, jak również aktywne kontakty Kłodzka z Pragą i Krakowem, skutkują wielokulturową historią z wyraźnym wątkiem polskim.

Wieloletni proces wznoszenia Twierdzy Głównej do obecnej postaci trwał od 1622 r. do pocz. XX w. Budowa, rozbudowa i liczne modyfikacje zespołu na Górze Zamkowej ilustrują burzliwą historię Kłodzka, są również zapisem ewolucji sztuki prowadzenia wojen i obronności. Dynamika architektonicznych przekształceń fortyfikacji odpowiada przynależności Kłodzka do kolejnych władców oraz zagrożeniom ze strony ówczesnych wrogów:

1) 1622 r. - w dobie czeskiej rebelii Kłodzko wraz z Zamkiem Dolnym i Górnym na Górze Zamkowej stało się punktem oporu względem Austrii. W ramach obrony zamku przed atakiem od północy powstał szaniec koronowy łączący trzy bastiony (późniejsze Dzieło Koronowe).

2) 1627-1740 - po zdobyciu miasta i zamku Austriacy rozpoczęli prace fortyfikacyjne na Górze Zamkowej w obawie przed zagrożeniem ze strony Szwedów. W toku prac zamek otoczono: od zachodu dwoma pierścieniami umocnień (wpierw Zamek Dolny włączono w wewnętrzny obwód obronny Dzieło Koronowe - Bastion Dzwonnik - Bastion Alarmowy, nadający Twierdzy charakter cytadelowy, później wzniesiono Półbastion Tumski, Kurtynę Tumską oraz Półbastion Orzeł i połączono je z murami miejskimi) oraz od północy (rawelinami Polnym i Jabłonką przed kurtynami Dzieła Koronowego). Jak wynika z aktualnego stanu badań nad Twierdzą Kłodzko, północną, bastionową część Twierdzy, opartą na rozwiązaniach szkoły holenderskiej, umocniły chodniki kontrminowe pod północnym przedpolem.

3) 1743 r. - po objęciu panowania przez Prusaków (1742) nastąpiła rozbudowa i modernizacja fortecy na podstawie projektu Walrawego, a podyktowana rozkazem Fryderyka II pragnącego umocnić kłodzką w celu utrzymania pozostałych śląskich zdobyczy5. Powstały

Historię miasta i Twierdzy Kłodzko opracowano na podstawie: Kłodzko dzieje miasta, pod red. R. Gładkiewicza, Kłodzko 1998, Bukal G., Twierdza Kłodzka 1620-1900, KAiU t. 31, z. 3-4/86 s. 279-322 oraz Małachowicz E., Twierdza Kłodzka, Zeszyty Muzeum Ziemi Kłodzkiej, z. 2: 1987, s. 3-30.

5 M. Małachowicz, Fortyfikacje przełęczy Sudetów, [w:] Nowożytne fortyfikacje Śląska .Twierdze Kłodzko i Srebrna Góra, seria wydawnicza Towarzystwa Przyjaciół Fortyfikacji „Fortyfikacja europejskim dziedzictwem kultury", t. XII, Warszawa 2000, s. 83. 
Wielkie Kleszcze (między Górnym Zamkiem a Dziełem Koronowym), szańce kleszczowe na stoku wschodnim i przy południowym wejściu do zamku. Front zachodni został wzmocniony o lunety i Wysoki Redan (tj. plac broni), a północny - o mocno wysuniętą lunetę Żuraw oraz nową fosę przed Dziełem Koronowym, tworzącą gwiaździsty płaszcz, który przedłużono aż do bastionu Orzeł na zachodnim stoku Góry Zamkowej. Pod północnym przedpolem rozbudowano istniejące korytarze w sieć chodników minerskich i kontrminowych, obejmujący sześć systemów na kilku poziomach.

-1744-1751 - na wschodnim brzegu Nysy Kłodzkiej powstał potężny fort pomocniczy Owcza Góra, stanowiący wybitny przykład staropruskiej szkoły fortyfikacyjnej i mający za zadanie wzmacnianie Twierdzy Głównej poprzez zabezpieczenie wschodniego i północnego przedpola Kłodzka oraz zablokowanie drogi na Wrocław. Założenie stanowi jednorodny i samodzielny fort o narysie gwiazdy, złożony z dwóch koron: Korony Niskiej w systemie kleszczowym na narysie moguncko-würzburskim ${ }^{6}$ oraz skazamatowanej Korony Wysokiej, połączonej barkami z częściowo skazamatowanymi lunetami i umocnionej reditą - „donżonem”.

Równolegle w obrębie ufortyfikowanego Przedmieścia Ząbkowickiego powstał szpital, koszary ze stajniami oraz dwa ogromne spichlerze, a także most śluzowy. Funkcja spiętrzenia wody miała zapewnić dodatkową ochronę wschodniego przedmieścia Kłodzka poprzez sztucznie wywołaną powódź.

- 1770-1774 - zastąpiono archaiczny Zamek Wysoki wyspecjalizowanym, trzykondygnacyjnym Donżonem o narysie kleszczowym, który uczynił z Twierdzy Głównej zintegrowany zespół obronny. Zmodyfikowano dzieła na południe od Donżonu: Bastion Wieżowy, Bastion Wysoki i Przeciwstraż zamku, co zapewniło wzajemne wsparcie ogniowe oraz pełne panowanie nad miastem i przeprawą na Nysie Kłodzkiej.

4) Pocz. XX w. - ostatnie modyfikacje zwiększające obronność Twierdzy stanowią schrony i stanowiska bojowe, zbudowane w obrębie korony Donżonu. Zbiegły się one w czasie z wyburzaniem murów i bram miejskich, wskutek czego Kłodzko przestało być ciasnym miastem garnizonowym i zaczęło rozrastać się o dzielnice willowe.

Reasumując walory architektoniczne Twierdzy Kłodzko, za nośniki wyjątkowej wartości zabytku uznać należy:

1) zespół fortyfikacji dominujący w przestrzeni miejskiej i przywołujący dawny charakter Kłodzka jako miasta garnizonowego (fot. 5);

2) nowatorstwo niektórych rozwiązań w rozwoju pruskiej sztuki fortyfikacji.

3) nawarstwienie nowożytnych rozwiązań fortyfikacyjnych oraz ich dobry stan zachowania;

\footnotetext{
6 O charakterystycznych dla Walravego systemach kleszczowo - bastionowych dzieł oraz ich kombinacji na tzw. „narysie moguncko-würzburskim” wspomina Izabela Kozłowska w rozprawie doktorskiej pt. Szczecińskie fortyfikacje nowożytne, rola fortyfikacji nowożytnych $w$ kształtowaniu układu przestrzennego miasta szczecina oraz wplyw analizy historycznej na wspótczesne działania projektowe i zakres ochrony konserwatorskiej, Szczecin 2007, s. 165; http://www.pbc.gda.pl/content/8063/phd_kozlowska_izabela.pdf (dostęp: 29.11.2019).
} 


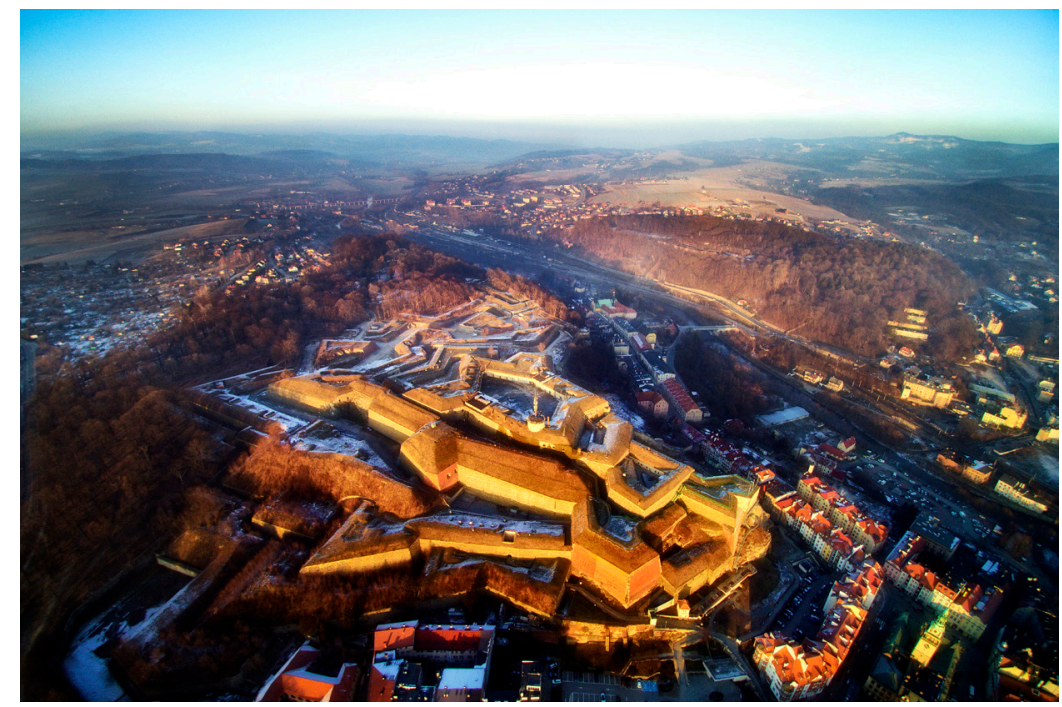

Fot. 5 Widok z lotu ptaka od zachodu na kompleks fortyfikacji kłodzkich. Na pierwszym planie Twierdza Główna, w tle Fort Owcza Góra (fot. G. Basiński)

\section{Twierdza Kłodzko - dziedzictwo bez dziedzica, czy dziedzic bez misji?}

Pomimo tych historycznych i architektonicznych walorów, Twierdza Kłodzko wciąż nie jest pomnikiem historii.

Zabytek miał szansę uzyskać to wyróżnienie w 2009 r. staraniem właściciela - Gminy Miejskiej Kłodzko ${ }^{7}$, jednak wniosek został odrzucony z powodu zgłoszenia zbyt dużego i nieautentycznego w całości obszaru Kłodzka ${ }^{8}$. W granicach wnioskowanego obszaru - poza uzasadnionym terenem powstałego w 2005 r. Fortecznego Parku Kulturowego-Twierdza Kłodzko ${ }^{9}$ znalazły się ponadto: przylegająca do FPK od południa starówka (do k. XIX w. objęta murami miejskimi) wraz z Wyspą Piasek ${ }^{10}$, a także część miasta przylegająca do murów miejskich od południa i zachodu, stanowiąca fragment dzielnicy powstałej na przełomie XIX i XX w., którą to część wnioskodawca ograniczył główną arterią miasta, tj. ul. T. Kościuszki.

Koncepcja wnioskodawcy o zgłoszeniu obszaru FPK poszerzonego o obszar starówki i fragment dzielnicy z eklektycznymi kamienicami zXIX i XX w. w opinii autorki jest trudna do uzasadnienia. Należy zauważyć, iż starówka $z$ historycznym układem urbanistycznym wpisana została do rejestru zabytków w 1956 r., kiedy stanowiła ona jeszcze oryginalny kompleks, fragmentarycznie

Gmina Miejska Kłodzko stała się właścicielem Twierdzy Kłodzko w 2007 r. po kilku latach starań (vide: http://orka2.sejm.gov.p1/IZ4.nsf/main/7504FD36 dostęp: 29.05.2019).

8 Zgodnie z informacją pozyskaną z Wydziału Rozwoju UM w Kłodzku.

9 Uchwała nr XLIII/355/2005 Rady Miejskiej w Kłodzku z dnia 27 października 2005 r. w sprawie utworzenia Fortecznego Parku Kulturowego - Twierdza Kłodzko w Gminie Miejskiej Kłodzko. Obszar FPK objął obie fortyfikacje i położone pomiędzy nimi dawne Przedmieście Ząbkowickie.

10 Stanowiąca historyczny układ urbanistyczny miasta Kłodzka (wpis do rejestru zabytków pod nr $370 \mathrm{z}$ dnia 25.11.1956 r.). 
naruszony poprzez zawalenie się pojedynczych kamienic w obrębie najstarszych ulic miasta (Czeskiej, ob. Armii Krajowej i ob. Łukasińskiego). Tymczasem zapoczątkowana w połowie lat 50. katastrofa budowlana w ciągu dekady unicestwiła kilkadziesiąt renesansowych i barokowych kamienic, miejsce których zajęly plomby i bloki typowe dla lat 60. i 70. Ostatnia pseudorekonstrukcja utraconych kwartałów zabudowy dotyczyła północnej pierzei rynku, którą w latach 90. „odtworzono” stylizowanymi nieudolnie kamienicami o zawyżonej wysokości, mocno zakłócającej pierwotny pejzaż miejski i jego dominanty w postaci masywu Twierdzy oraz strzelistej, renesansowej wieży ratusza.

Brak autentyczności i jednorodności rozległych części starówki stanowi podstawowy zarzut wobec wniosku z 2009 r., jednak równie kuriozalne było włączenie do wnioskowanego obszaru części dzielnicy eklektycznych kamienic czynszowych i willi mieszczańskich, która nie pokrywa się z granicą wszystkich umocnień fortyfikacyjnych Kłodzka ${ }^{11}$. Specyfika wnioskowanego obszaru miejskiego: niejednorodnego, pozbawionego autentyczności w zbyt wielu kwartałach, sztucznie podzielonego i przede wszystkim nie odpowiadającego zachowanej linii umocnień, wskazuje na determinację wnioskodawcy do wpisania na listę pomników historii nie tyle Twierdzy Kłodzko, co znacznej części miasta Kłodzka wraz z Twierdzą, dla której to idei Twierdza Kłodzko miała być przede wszystkim swoistym gwarantem uzyskania oczekiwanego rezultatu.

Ta krytyczna ocena ówczesnych intencji właściciela wobec zabytku nie jest bezpodstawna. Począwszy od niezrealizowanych deklaracji złożonych przez burmistrza Kłodzka w momencie przejęcia Twierdzy na własność przez Gminę Miejską w $2007 \mathrm{r} .{ }^{12}$ poprzez perturbacje związane z realizacją zapisów uchwały powołującej Forteczny Park Kulturowy-Twierdza Kłodzko, a skończywszy na budzącej spore wątpliwości sprawie dzierżawy fortu pomocniczego Owcza Góra - miniona dekada pokazuje co najmniej brak zrozumienia rangi zabytku przez jego właściciela, a także związany z tym brak misji ochrony zabytku, o zrównoważonej adaptacji nie wspominając ${ }^{13}$.

O ile powołanie w 2005 r. FPK-Twierdza Kłodzko mogło świadczyć o wysokiej świadomości ówczesnych władz miasta na temat rangi zabytku oraz konieczności wieloaspektowej ochrony kompleksu fortyfikacji, o tyle proces wdrażania tej idei jest wyrazem zgoła lekceważącego

\footnotetext{
11 Powstałe w podobnym okresie i reprezentujące ten sam styl kamienice czynszowe oraz wille ulokowane są również na południe od ob. ulicy T. Kościuszki, stanowiącej granicę wnioskowanego obszaru. Właściwy zasięg dzielnicy wyznacza ob. ulica Chopina, rozciągnięta między meandrem nurtu Nysy Kłodzkiej od wschodu i zabudowaniami penitencjarnymi od zachodu. Zdaniem autorki punktami granicznymi dla ewentualnego (!) poszerzenia wnioskowanego obszaru powinny być elementy umocnień fortyfikacyjnych wysunięte na południowe i wschodnie przedpola miasta.

12 http://www.walbrzych.info/pl/wiadomosci,News,2396,twierdza-zdobyta.html (dostęp: 2.06 .2019 r.).

13 Termin „równoważonej adaptacji” został przejęty od Łukasza Pardeli i Katarzyny Pałubskiej: Pardela Ł., Pałubska K., Krajobraz w zrównoważonej adaptacji zabytkowych fortyfikacji (...), [w:] Ochrona wartości w procesie adaptacji zabytków, praca zbior. pod red. B. Szmygina, Warszawa 2015, s. 221-228.
} 
podejścia władz do tematu ${ }^{14}$. Najdobitniej ilustruje ów fakt sposób zarządzania Twierdzą, niezgodny z treścią zapisu uchwały: zamiast utworzenia jednostki zarządzającej FPK wraz z wyłonionym w drodze konkursu kompetentnym kierownikiem, zarządzanie Twierdzą Główną i Fortem Owcza Góra powierzano różnym instytucjom, nie dającym gwarancji objęcia zabytku należytą ochroną: na pocz. 2006 r. turystyczną część Twierdzy Głównej powierzono OSIR, w okresie kwiecień 2007 - wrzesień 2010 r. OSIR zarządzał całym obszarem Twierdzy Głównej i Fortem Owcza Góra, po czym teren ten oddano w 30-letnią dzierżawę spółce miejskiej ZAMG Sp. z o. o. w celu realizacji inwestycji budowy kolei gondolowej (!) łączącej dwa forty, wreszcie w marcu 2014 r oddano cały Fort Owcza Góra oraz część Twierdzy Kłodzko w 40 letnią dzierżawę spółce Wadex Inwest Sp. z o. o. (z kapitałem zakładowym 50000 zł), również w celu budowy kolei gondolowej i zagospodarowania obiektu ${ }^{15}$. Sama idea budowy kolei gondolowej między fortami - przy jednoczesnym braku podjęcia poważniejszych prac konserwatorskich w obrębie fortyfikacji oraz budzącej wątpliwości wycince drzew w forcie Owcza Góra - wywołuje refleksje na temat priorytetów właściciela obiektu. Co więcej: niepowtarzalność i atrakcyjność turystyczna kolejki gondolowej nie jest wystarczającym argumentem przemawiającym za realizacją tej koncepcji (skądinąd ingerującej w zabytkowy pejzaż forteczny), skoro równie atrakcyjny dla turystów, a przy tym bezsprzecznie unikatowy, byłby wjazd kolejką na Twierdzę Główną poprzez przywrócenie komunikacji oryginalnej poterny z $1873 \mathrm{r}$. pod wschodnim stokiem. Ocenę autorki, iż priorytetami właściciela nie były ani misja ochrony zabytków, ani program ich zrównoważonej adaptacji, potwierdza kontrowersyjna i karykaturalna koncepcja zagospodarowania Fortu Owcza Góra przez jego byłego dzierżawcę (Wadex Invest Sp. z o. o.). Zaprzecza ona postulatom zawartym choćby w Karcie Weneckiej (skoncentrowanym na zachowaniu dziedzictwa przeszłości dla kolejnych pokoleń), za to ilustruje ignorancję wobec zasad ochrony zabytku oraz brak szacunku i zrozumienia wobec jego dziedzictwa ${ }^{16}$.

Zespół negatywnych cech, którymi wykazał się właściciel Twierdzy Kłodzko w ciągu kilku lat od uzyskania tytułu własności, położył się cieniem również na Twierdzy Głównej. W jej obrębie w 2011r. „wyremontowano” Wielkie Kleszcze adaptując je do funkcji ekspozycyjnej

14 Na temat zawiłych okoliczności powstawania i wdrażania FPK - Twierdza Kłodzko, jak również obecnego funkcjonowania Twierdzy Kłodzko w obrębie struktury Parku, w październiku 2017 r. autorka wygłosiła referat podczas Międzynarodowej konferencji naukowej 15 lat Fortecznego Parku Kulturowego w Srebrnej Górze. Ochrona i zarzadzanie zabytkowymi zespołami architektury obronnej (http://www.icomos-poland.org/pl/ archiwum-aktualnosci/201-miedzynarodowa-konferencja-naukowa-15-lat-fortecznego-parku-kulturowegow-srebrnej-gorze-ochrona-i-zarzadzanie-zabytkowymi-zespolami-architektury-obronnej.html.

dostęp: 20.04.2019); materiały pokonferencyjne są w przygotowaniu.

15 O skomplikowanej i dynamicznej akcji wydzierżawienia Owczej Góry spółce-matce Wadex S.A., a następnie spółce-córce Wadex Invest, a także o zarzutach Burmistrza Michała Piszki dotyczących nielegalnej wycinki drzew i zniszczenia zabytku, skutkujących wypowiedzeniem dzierżawy w marcu 2015 r. m. in.: Awiżeń M., Wadex Invest i Fort Owcza Góra, [w:] http://nowa.mojabrama.pl/wadex-invest-i-fort-owcza-góra (dostęp: 25.04.2019), a także Śledź A., Spółka Wadex pozwała Kłodzko do sądu o $10 \mathrm{mln}$ złotych [w:] http://www.gazetawroclawska.pl/ strefa-biznesu/firma/a/spolka-wadex-pozwala-klodzko-do-sadu-o-10-mln-zlotych,10168754/.

(dostęp: 25.04.2019).

16 Bieńkowski B., Zwycięska wizja fortu „Owcza Góra”, [w:] http://dkl24.pl/pl/a/926/zwycieska-wizja-fortu---owcza-gora---.html (dostęp: 25.01.2018). 
i konferencyjnej. Lista przewinień względem zabytku obejmuje m. in.: wyprucie w partii fundamentów wewnątrz kazamaty oryginalnego mechanizmu kieratu, uruchamiającego kolejkę w poternie pod wschodnim stokiem oraz zastąpienie oryginalnej ceglanej posadzki w układzie opusspicatum płytką klinkierową układaną na mijankę, otynkowanie pierwotnych ceglanych ścian kazamat grubym tynkiem strukturalnym odzwierciedlającym ruch pacy, wreszcie zdemolowanie korony dzieła w ramach prac izolacyjnych poprzez trwałe zniszczenie pokrywy roślinnej i złe wyprofilowanie wału, wskutek czego woda opadowa spływa z gliniastym błotem bezpośrednio po odnowionych murach, przy jednoczesnym zatykaniu kanałów odwodnieniowych.

Być może udałoby się uniknąć powyższych błędów - karygodnych z punktu widzenia konserwatora i historyka sztuki - gdyby właściciel zabytku, zgodnie z uchwałą powołującą FPK, korzystał z narzędzia monitorowania zabytkowego kompleksu ${ }^{17}$. Tymczasem zaniechania włodarza miasta w zakresie ochrony zabytków nie ograniczyły się wyłącznie do obszaru Fortecznego Parku - w 2011 r. decyzją burmistrza Kłodzka zlikwidowane zostało stanowisko Miejskiego Konserwatora Zabytków.

Wątpliwa jakość przeprowadzonych remontów, nie uwzględniająca zabytkowej i oryginalnej tkanki obiektu oraz kwestionująca rzetelne podejście właściciela zabytku do Twierdzy Kłodzko, wymaga szukania rozwiązań systemowych, będących z jednej strony gwarantem objęcia kłodzkich fortyfikacji należytą ochroną, a z drugiej konstytuujących prestiż obiektu.

Ranga tytułu pomnika historii mogłaby dać Twierdzy Kłodzko właściwy status i swoisty immunitet, trzymający decyzyjnych lokalnych ignorantów na bezpieczny dystans.

\section{Twierdza Kłodzko - dziedzictwo niechciane?}

Zgodnie $\mathrm{z}$ opisem dostępnym na stronach Narodowego Instytutu Dziedzictwa ${ }^{18}$, na liście pomników historii „znajdują się obiekty o szczególnych wartościach materialnych i niematerialnych oraz znaczeniu dla dziedzictwa kulturowego naszego kraju". Zważywszy na niepodważalne walory architektoniczne Twierdzy Kłodzko, obecność tej fortyfikacji wśród innych znakomitych zabytków Polski ma silne uzasadnienie. Polskie wątki w wielokulturowej historii kłodzkiej twierdzy dodają jej wartości w kontekście uhonorowania miejsca pamięci lub postaci historycznych. Większość z tych wątków dotyczy działań narodowowyzwoleńczych oraz martyrologii Polaków: Wojciech Kętrzyński odsiadywał tu roczny wyrok w dobie Powstania Styczniowego (1864-65), z kolei podczas II Wojny Światowej został tutaj stracony Władysław Planetorz (1944), a w zorganizowanym na terenie Twierdzy obozie pracy, przy częściach radiotechnicznych do łodzi podwodnych oraz rakiet V-2, przymusowo pracowało 1500 polskich robotników, których ewakuowano z Łodzi wraz z fabryką AEG. Wątkiem nie mniej istotnym dla

\footnotetext{
17 W okresie od lipca 2008 r. do końca roku 2011 aktywny monitoring był prowadzony przez jednego z członków Rady Konsultacyjno-Naukowej, Mirosława Rzytkiego, w ramach realizacji Uchwały nr XLIII/355/2005, jednak dokonywane przez niego zgłoszenia pozostawały bez odzewu ze strony UM, a (dość niewygodna) aktywność monitorującego poskutkowała jego nieformalnym odwołaniem z funkcji; od maja 2012 do listopada $2013 \mathrm{r}$. monitoring powierzono Kamili Pietkiewicz, a w 2014 r. Burmistrz zupełnie zlikwidował monitoring FPK.

18 https://www.nid.pl/pl/Informacje_ogolne/Zabytki_w_Polsce/Pomniki_historii/ (dostęp: 31.05.2019).
} 
historii Polski jest postać św. Wojciecha, patrona Polski i syna Sławnika, który był pierwszym udokumentowanym władcą Kłodzka, urzędującym na Górze Zamkowej w 981 r. ${ }^{19}$

Pomimo tego komponentu wartości, jakim dysponuje Twierdza Kłodzko, panujący w ostatnich latach na płaszczyźnie kultury „narodowy ton” wywołuje niepokój o obiektywne spojrzenie, zarówno na stan zabytków objętych granicami obecnej Rzeczypospolitej, jak i o sprawiedliwą czyli uzasadnioną owym stanem oraz wartościami historycznymi i artystycznymi - kuratelę nad nimi. Obawy autorki o ignorowanie potrzeb zabytków zachodniej Polski znalazły swój fundament w głównych założeniach polityki Ministerstwa Kultury i Dziedzictwa Narodowego na lata 20172020, zaprezentowanych przez ministra Jarosława Sellina w maju 2017 r. na Walnym Zjeździe Delegatów Stowarzyszenia Muzealników Polskich ${ }^{20}$ i skoncentrowanych na dwóch nurtach: zbrodniach wojennych, martyrologii i bohaterstwa narodu polskiego ${ }^{21}$ oraz swoistej apoteozy Polski poprzez przywołanie jej zwycięstw i niegdysiejszej potęgi ${ }^{22}$. Znamienne, iż wśród wielu inicjatyw wymienionych przez ministra Sellina, których podjęło się MKiDN, najdalej wysuniętą na zachód instytucją muzealną, której działalność Ministerstwo wzięło pod swoją organizacyjną i finansową pieczę, było Centralne Muzeum Jeńców Wojennych w Łambinowicach-Opolu. Gdyby ta optyka miała okazać się obowiązująca również wobec ochrony zabytków, nie byłoby w niej miejsca na Twierdzę Kłodzko.

Choć w dziedzinie ministerialnych dotacji na ochronę zabytków w minionym roku dostrzegalna była atencja wobec województwa dolnośląskiego ${ }^{23}$, to jednak głosy części uczestników konferencji poświęconej pomnikom historii każą trzymać ów entuzjazm na wodzy.

Sygnały, które wybrzmiały i które mogą niepokoić opiekunów zabytków w zachodniej części Polski, wskazywały na konieczność objęcia ochroną w pierwszej kolejności zabytki związane z postaciami szczególnie ważnymi dla historii i tożsamości Polaków, a także zabytki stanowiące świadectwo dziedzictwa narodowego na terenach dawnej Rzeczpospolitej, które w obrębie nowych granic terytorialnych są skazane na postępującą degradację.

Chociaż trudno odmówić racji tym argumentom, ich wybrzmienie podczas konferencji sugeruje

19 W bieżącym roku podjęto działania zmierzające do wpisania Kłodzka i Twierdzy Kłodzko w przyszłym roku na Międzynarodowy Szlak św. Wojciecha: https://gazetawroclawska.pl/na-dolnym-slasku-powstaje-szlaksw-wojciecha/ar/10156092 (dostęp 2.06.2019).

20 W Zjeździe tym autorka brała udział, a przytoczone tu informacje pochodzą z własnej notatki sporządzonej na podstawie wystąpienia ministra J. Sellina.

${ }^{21} \quad$ Ilustrowany poprzez wątek zagłady Żydów (nowa organizacja muzeum w Treblince, plany opracowania struktur organizacyjnych muzeum w Sobiborze i prace dotyczące obozu w Płaszowie) wraz z upamiętnieniem ludności zaangażowanej w ratowanie Żydów (plany założenia Muzeum Sprawiedliwych pod Oświęcimiem), a także poprzez temat golgoty Sybiraków (plany założenia muzeum tematycznego w Białymstoku).

22 Realizacja tych idei przejawiła się w projekcie „Niepodległa” w ramach uczczenia 100-lecia odzyskania niepodległości, ponadto na 2019 r. planowano celebrowanie 450 rocznicy Unii Lubelskiej i Rzeczpospolitej Obojga Narodów.

23 W jesiennym naborze 2018 r. w pierwszej dziesiątce zabytków z największą dotacją znalazły się cztery dolnośląskie zabytki zajmując wysokie lokaty: 1, 2, 5 i 6. http://www.mkidn.gov.pl/media/po2019/ wyniki_/20190514_Karta_publikacji_Ochrona_zabytkow_2019_I_nabor_(z_odwolaniami).pdf. (dostęp: 5.06.2019). 
brak poparcia części środowiska konserwatorskiego wobec nominowania do tytułu pomnika historii zabytków, które nie dotyczą bezpośrednio historii Polski. Taka postawa groziłaby Twierdzy Kłodzko, dla oceny której należy przyjąć szerszy kontekst, przytoczony choćby w parafrazie wypowiedzi prof. Piotra Molskiego: zarówno rodzime, jak i obce fortyfikacje, przede wszystkim: francuskie, rosyjskie i radzieckie, pruskie i niemieckie oraz austriackie (...) stanowia materialny zapis burzliwej historii Polski, symbol przetrwania i zachowania naszej narodowej tożsamości, ale też trwaly ślad ewolucji sztuki fortyfikacyjnej wielkich mocarstw, uznawany za europejskie dziedzictwo kulturowe ${ }^{24}$. O europejskiej randze dziedzictwa twierdz fryderycjańskich, dominujących $\mathrm{w}$ fortecznym krajobrazie zachodnich województw Polski, wspomina także Edmund Małachowicz, który ocenia te fortyfikacje jako najbardziej „europejskie” pod kątem autorstwa koncepcji i ewolucji myśli inżynieryjnej ${ }^{25}$.

Również dla zabytków w zachodniej Polsce, widniejących już na liście pomników historii, realizowanie takiej strategii niosłoby za sobą zagrożenie brakiem skutecznego wsparcia finansowego wobec ograniczonego budżetu MKiDN, w żadnej mierze nie odpowiadającego realnemu zapotrzebowaniu. Dla Twierdzy Kłodzko, jako kandydata do wpisania na listę pomników historii, nie mniej niepokojącą propozycję stanowią głosy o przeformułowaniu definicji pomników historii, tudzież wprowadzeniu selekcji kandydatów i limitowaniu przyznawania tego tytułu, co miałoby się przełożyć na podniesienie jego rangi.

Gdyby tej koncepcji przyświecało wyłącznie odpowiedzialne kreowanie marki zabytku będącego pomnikiem historii, pod wieloma względami wyjątkowego na tle innych analogicznych obiektów, Twierdza Kłodzko z uwagi na swoje walory i przy zastosowaniu obiektywnych kryteriów miałaby szansę otrzymać ów zaszczytny tytuł. Jednakże tytuł Pomnika Historii daje zabytkowi dodatkowe punkty w procesie uzyskania dofinansowania od $\mathrm{MKiDN}^{26}$, co może stanowić szczególną motywację do podjęcia starań o wpisanie zabytku na listę pomników historii. Tym samym system wartościowania zabytków, mający na celu zwiększenie zakresu ochrony tych rzeczywiście najwartościowszych obiektów, może okazać się niewydolny. Istnieje bowiem ryzyko, iż wobec ograniczonego budżetu MKiDN, o rozbudowie listy nie będzie decydować obiektywna analiza walorów historycznych, naukowych i artystycznych zabytku, ale interes finansowy obecnych pomników historii, dla których kolejne obiekty wyróżnione tytułem stanowić będą konkurencję.

\footnotetext{
24 Molski P., Ochrona i zagospodarowanie wybranych zespołów fortyfikacji nowszej w Polsce, „Prace Naukowe Politechniki Warszawskiej. Seria Architektura", 2007, nr 3, s. 3-132.

25 Małachowicz E., Nowożytne fortyfikacje Ślaska europejskim dziedzictwem kultury, [w:] Nowożytne fortyfikacje Śląska (...), s. 8.

${ }^{26}$ Z czterech dolnośląskich zabytków, które otrzymały jedne z najwyższych dofinansowań w naborze jesiennym w 2019 r., aż trzy posiadają status pomnika historii.
} 


\section{Pomnik Historii jako prestiż i gwarancja skutecznej ochrony}

Kwestie poruszone podczas konferencji nt. pomników historii były przez autorkę rozważane przede wszystkim pod kątem casusu Twierdzy Kłodzko, o której wpisanie na listę pomników historii ponownie podjęto starania. Refleksje towarzyszące poszczególnym referatom oraz dyskusji sprowadzają się do następujących uwag i postulatów:

1) Ocena zabytku na podstawie jego uniwersalnej wartości.

W opisie idei pomnika historii powinno wyraźnie wybrzmieć kryterium uniwersalnej wartości zabytku jako dziedzictwa kulturowego, nie ograniczonego i niezdeterminowanego kontekstem wyłącznie narodowym. Polski „Pomnik Historii” to nie to samo, co „Pomnik Historii Polski” - tytuł nadawany wyjątkowym zabytkom w Polsce nie wskazuje na ich „aspekt narodowy”. Z kolei definicja mówiąca, iż terminem tym określa się zabytek nieruchomy o szczególnym znaczeniu dla kultury naszego kraju, sprzyja weryfikacji zabytku pod względem jego walorów narodowościowych, co wobec coraz bardziej powszechnego dyskursu zamyka Twierdzę Kłodzko w uproszczonym i nierzetelnym kontekście. Jest oczywistym, iż nadrzędną cechą zabytku jest jego uniwersalna wartość jako dziedzictwa kulturowego, natomiast ulokowanie zabytku na terenie obecnej Rzeczypospolitej to dodatkowy przymiot w postaci kontekstu geograficznego i historycznego. Uniwersalna wartość dziedzictwa w skali Europy wyróżnia wyjątkowe i rozpoznawalne zabytki wpisane na listę pomników historii, które nie prezentują stricte polskiego dziedzictwa i które w czasie ich powstawania czy funkcjonowania nie miały przełożenia na kulturę naszego kraju: Twierdza Srebrna Góra (wpis w roku 2004), ewangelickie Kościoły Pokoju w Świdnicy i Jaworze (2017), Muzeum Papiernictwa w Dusznikach (2011), czy Hala Stulecia we Wrocławiu (2005). Kryterium zastosowane w przypadku powyższych obiektów powinno zostać sformalizowane dla zapewnienia merytorycznego procesu weryfikacji kolejnych kandydatów do tytułu pomnika historii.

Wszystkie kryteria kwalifikacji kandydatów powinny być obiektywne, tj. oparte na analizie wartości historycznej, architektonicznej, artystycznej i naukowej, jak również na ocenie stanu zachowania. Inspiracją dla określenia tych kryteriów mogłyby być kryteria wyjątkowej uniwersalnej wartości (OUV) Światowego Dziedzictwa UNESCO.

\section{2) Finansowanie}

Nie ulega wątpliwości, iż budżet na ochronę zabytków powinien zostać zdecydowanie zwiększony, a udzielone dotacje powinny mieć możliwość rozliczenia w okresie dłuższym, niż rok. Prace konserwacyjne przy zabytkach wymagają czasu, którego pozbawiają warunki pogodowe oraz administracyjne wymogi (np. zamówienia publiczne). Konieczność rozliczania dotacji w ciągu roku kalendarzowego naraża zabytki na błędy w sztuce i pozorną, kosmetyczną konserwację. Ponadto dystrybucja środków finansowych do poszczególnych regionów nie powinna ograniczać się wyłącznie do rangi dotowanego dziedzictwa (np. Kraków), ale dodatkowo uwzględniać stan zachowania zabytków, możliwość pozyskania środków z innych źródeł, wpływ dotacji na dalsze samodzielne funkcjonowanie obiektu wskutek zrównoważonej adaptacji, etc. 
3) Rola konserwatora i ranga tytułu pomnika historii w procesie skutecznej ochrony zabytku. Wobec opieszałości lub lekceważącego stosunku władzy, albo wobec jej wybiórczego i przedmiotowego podejścia do dziedzictwa, nierzadko wykorzystywanego do celów politycznych, należałoby poszerzyć kompetencje konserwatora zabytków oraz wyposażyć go w niezbędne narzędzia (etaty, wyższe uposażenie, etc.), które pozwoliłyby sprawować ten urząd z należytą odpowiedzialnością i starannością. To bowiem na barkach konserwatorów spoczywa ciężar ochrony zabytku przed zakusami decyzyjnych ignorantów będących okresowo u władzy. Sam tytuł pomnika historii powinien stanowić nie tylko zobowiązanie generalnego konserwatora oraz Ministra Kultury i Dziedzictwa Narodowego do otoczenia zabytku stosowną ochroną i finansowym zapleczem. Pomnik historii powinien stanowić dla zabytku immunitet nietykalności przed pochopną polityką władz (do czego potrzebne są rozwiązania prawne wraz z systemem kar). Z kolei dla lokalnej społeczności pomnik historii powinien być powodem do dumy, na kanwie którego mieszkańcy zidentyfikują się z obiektem i będą współtworzyć jego genius loci27.

Refleksja nad tym, czy Twierdza Kłodzko stanowi dziedzictwo niechciane, wywołuje tym większy imperatyw zapewnienia jej należytej ochrony.

Gdyby jednak ochrony tej nie mogło roztoczyć Państwo, to kto?

${ }_{27}$ Lewicka M. L., Kulturowe i społeczne wartości mazowieckich zamków w Liwie i Iłży, [w:] Zamki w ruinie zasady postępowania konserwatorskiego, praca zbior. pod red. B. Szmygina i P. Molskiego, Warszawa - Lublin 2012, s.169-170. 


\section{Bibliografia}

Bukal G., Twierdza Kłodzka 1620-1900, KAiU t. 31, z 3-4/86.

Kłodzko dzieje miasta, praca zbior. pod red. R. Gładkiewicza, Kłodzko 1998.

Lewicka M. L., Kulturowe i społeczne wartości mazowieckich zamków w Liwie i Iłży, [w:] Zamki w ruinie - zasady postępowania konserwatorskiego, praca zbior. pod red. B. Szmygina i P. Molskiego, Warszawa - Lublin 2012.

Małachowicz E., Twierdza Kłodzka, Zeszyty Muzeum Ziemi Kłodzkiej, z. 2: 1987.

Małachowicz E., Nowożytne fortyfikacje Śląska europejskim dziedzictwem kultury, [w:] Nowożytne fortyfikacje Ślaska. Twierdze Kłodzko i Srebrna Góra, seria wydawnicza Towarzystwa Przyjaciół Fortyfikacji „Fortyfikacja europejskim dziedzictwem kultury”, t. XII, Warszawa 2000.

Małachowicz M., Fortyfikacje przełęczy Sudetów, [w:] Nowożytne fortyfikacje Ślaska. Twierdze Kłodzko i Srebrna Góra, seria wydawnicza Towarzystwa Przyjaciół Fortyfikacji „Fortyfikacja europejskim dziedzictwem kultury", t. XII, Warszawa 2000.

Molski P., Ochrona i zagospodarowanie wybranych zespołów fortyfikacji nowszej w Polsce, „Prace Naukowe Politechniki Warszawskiej. Seria Architektura", nr 3, 2007.

Pardela Ł., Pałubska K., Krajobraz w zrównoważonej adaptacji zabytkowych fortyfikacji (...), [w:] Ochrona wartości w procesie adaptacji zabytków, praca zbior. pod red. B. Szmygina, Warszawa 2015.

\section{Źródła internetowe}

Awiżeń M., Wadex Invest i Fort Owcza Góra, [w:] Awiżeń M.: http://nowa.mojabrama.pl/wadexinvest-i-fort-owcza-góra (dostęp: 25.04.2019).

Bieńkowski B., Zwycięska wizja fortu „Owcza Góra”, [w:] http://dkl24.pl/pl/a/926/zwycieskawizja-fortu----owcza-gora---html (dostęp: 25.01.2018).

Definicja Pomnika Historii https://www.nid.pl/pl/Informacje_ogolne/Zabytki_w_Polsce/ Pomniki_historii/ (dostęp: 31.05.2019).

Śledź A., Spółka Wadex pozwała Kłodzko do sądu o $10 \mathrm{mln}$ złotych [w:] http://www. gazetawroclawska.pl/strefa-biznesu/firma/a/spolka-wadex-pozwala-klodzko-do-sadu-o-10mln-zlotych,10168754/ (dostęp: 25.04.2019).

Zapis polityki lokalnych władz wobec zabytku: http://www.walbrzych.info/pl/ wiadomosci,News,2396,twierdza-zdobyta.html (dostęp: 2.06.2019 r.).

Zapis starań Gminy Miejskiej Kłodzko o przejęcie Twierdzy Kłodzko na własność http://orka2. sejm.gov.pl/IZ4.nsf/main/7504FD36 (dostęp: 29.05.2019).

Wynik naboru w programie MKiDN w 2018 r. http://www.mkidn.gov.pl/media/po2019/ wyniki_/20190514_Karta_publikacji_Ochrona_zabytkow_2019_I_nabor_(z_odwolaniami). pdf (dostęp: 5.06.2019). 